\title{
John Kinards STEMme
}

\author{
Marc Maure
}

John Kinard fra Anacostia $i$ Washington D. C. var museumsmannen som sa at "the museums must demonstrate how the power of knowledge can transform man's life". Tidlig i 70-årene begynte museumsfolk i mange land à høre om John Kinard (19361989) fra Anacostia Neighborhood Museum, som holdt til i en nedlagt kino i Martin Luther King Avenue, blant den fargede befolkningen $i$ den amerikanske hovedstad Washington D.C.

You would never know from visiting the average American museum that the black man exists in America and has made significant contributions toward the development of our country. (Kinard 1972b)

For alle som søkte en ny mening i museumsarbeidet, ble Anacostia Neighborhood Museum selve symbolet på fornyelsen.

We need museums that are designed to take risks: to bridge the gap between the rich and the poor, the educated and the uneducated, between those cultures that have been favoured and those that have been neglected. (Kinard 1972b).

I dag har de fleste museumsfolk sannsynligvis glemt John Kinard og Anacostia Neighborhood Museum, i hvertfall i vår rike del av verden. Vi har blitt mer opptatt av markedskreftenes logikk, og mener vel at god PR-strategi, vakre butikker og innsikt $i$ våre kunders atferd, er det som skal til for å gjøre våre museer mer levende. Det er noe i det, men likevel tror jeg fortsatt at John Kinard sa det viktigste, allerede for 30 år siden:
If museums are to meet the needs of the man of today and tomorrow, they must involve themselves in every area of human existences. This is a responsibility that challenge their most creative resources.

\section{Fra Neighborhood Museum til Center for African American History and Culture}

Anacostia Neighborhood Museum ble opprettet i 1967 som en desentralisert avdeling av verdens største museum, the Smithsonian Institution i Washington D.C. Noen år senere, ble det satt på listen over verdens mest betydningsfulle museer, sammen med bl.a. Louvre og National Gallery, av den innflytelsesrike museumskritiker og prisutdeler Kenneth Hudson (Hudson 1987).

På grunn av sin banebrytende virksomhet 
Anacostia Neighborhood Museum inrättades $i$ den nerlagda Carver-biografen vid Martin Luther King Jr Avenue. Museet öppnade i september 1967 och fanns här till 1987. Foto: Smithsonian Institution 1998.

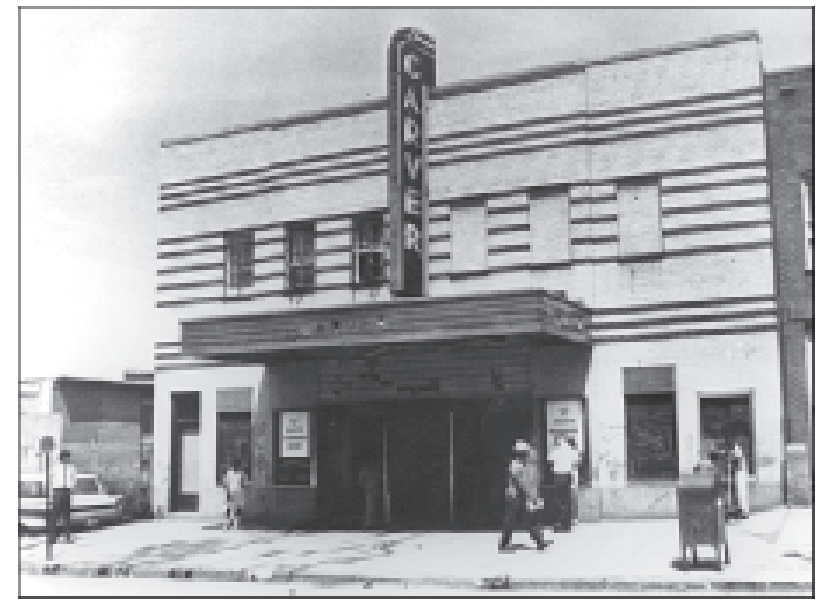

knyttet til afro-amerikanernes historie og livssituasjon, ble Anacostia Neighborhood Museum selve emblemet for the Black Museums Movement, som bidro til å endre USAs museumslandskap i 1970- og 80-årene. Museet gjennomgikk etterhvert en unik og interessant utvikling, fra å være en nærmiljø-orientert institusjon, til dagens status som nasjonalmuseum for afro-amerikanernes kultur, under navnet Anacostia Museum and Center for African American History and Culture.

Sett i internasjonalt perspektiv, framtrer slutten av 60-årene og begynnelsen av 70-årene som en periode preget av omfattende debatt om museenes rolle i samfunnet. Det foregikk på denne tiden en betydelig fornyelse, i form av modernisering av de tradisjonelle institusjonene, og skaping av nye museumsmodeller - Neighborhood Museums, Ecomusées, Casa del Museo, m.fl.

I USA var museumsdebatten sterkt preget av Borgerrettsbevegelsen (Civil Rights Movement) med fokus på den kulturelle undertrykkelsen som den svarte befolkningen var gjenstand for.
Afro-amerikanernes historie og kultur var stort sett fraværende fra de amerikanske museene; hittil var det i hovedsak svarte universiteter og biblioteker som hadde bygd opp samlinger, og kirker hadde fungert som utstillingsplass. Situasjonen begynte å endre seg fra siste halvdel av 60-årene, og i årene som fulgte ble mange museer viet den afro-amerikanske kunst og kultur etablert forskjellige steder i USA.

Opprettelsen av neighbourhood museums, dvs. bydel-/nærmiljømuseer, ble en viktig strategi i første fase av the Black Museums Movement. Dette skjedde i regi av mange ulike grupper, foreninger og institusjoner. Det var ikke uvanlig at store og godt etablerte museer tok initiativ, som del av "outreach programs» som tok sikte på å nå ut til nye publikumsgrupper, bl.a. etniske minoriteter.

I 1966 bestemte The Smithsonian Institution i Washington "to take the museums to the people». The Smithsonian danner verdens største kompleks av museer, de fleste med nasjonal status og lokalisert på The Mall, et område i Washington som utgjør USA største 


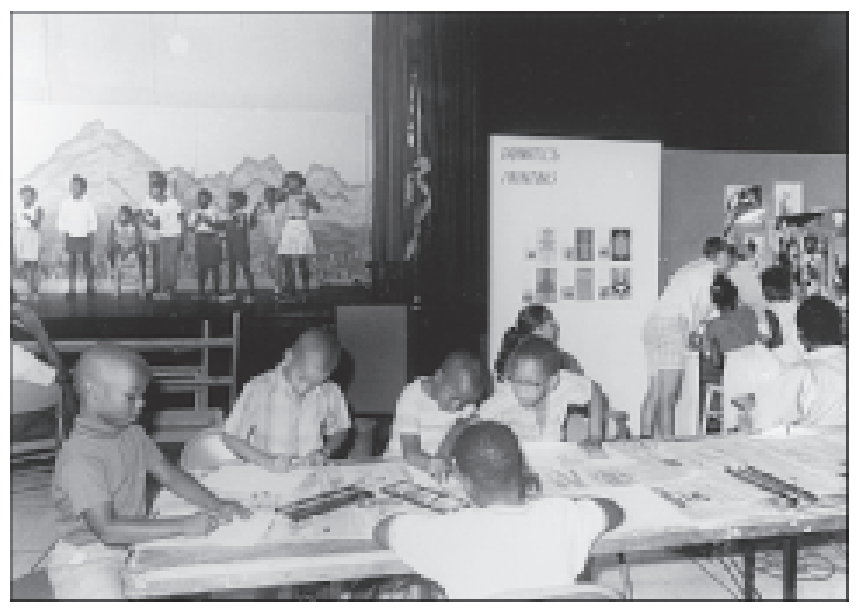

konsentrasjon av museer, parker og historiske minnesmerker av ulike typer. (http://si.edu/ museums/).

The Smithsonian ønsket å opprette

a mediatory museum between the population of a given area and the sponsoring institution» (Kinard 1972), an experimental store-front museum ... that would reach beyond the Mall (because) the museums on the Mall were very big and formal and very restricted ..., arouse curiosity and stimulate motivation for further learning (Marsh 1968).

En tenkte på en satelitt-institusjon uten egne samlinger, som ville fungere som utpost og utstillingsvindu i et marginalt og folkelig område, dvs. bidra til å bryte ned barrierer og føre til økt museumsbruk.

At museet ble noe annet og mye mer enn det, skyldes for det første at The Smithsonian la meget stor vekt på dialog med ulike lokale interessegrupper. Dette preget prosessen som gikk ut på å identifisere den aktuelle bydelen som ble Anacostia, et område tradisjonelt bebodd av et flertall av fargede og preget av sosi- ale problemer - og videre under selve planleggingen og driften av museet. I tillegg førte valget av den energiske og karismatiske John Kinard til direktør, som styrte museet helt til sin død i 1989, til at funksjonene som store-fronteller mediatory museum raskt kom i bakgrunnen, til fordel for en prioritering av museets rolle som redskap for bevisstgjøring og utvikling av lokalsamfunnet.

The neighborhood museum exists to serve the people of the area of which it is a part ... it concerns itself with an analysis of the community and its history. It poses such questions as where did we come from, who are our heroes, what is our heritage, who are we as a people? ... The focus is on the problems, aspirations, hopes, fears, difficulties, and dreams of its constituents. As the museum increases its understanding and awareness of its function and purpose, the community also begins to discover its identity through the museum and to take pride in that identity. ... People who have no decent place to live or lack educational skills have no interest in air pollution or græco-roman civilization. They are forced to concentrate on the struggle to sur- 
Marc Maure

112

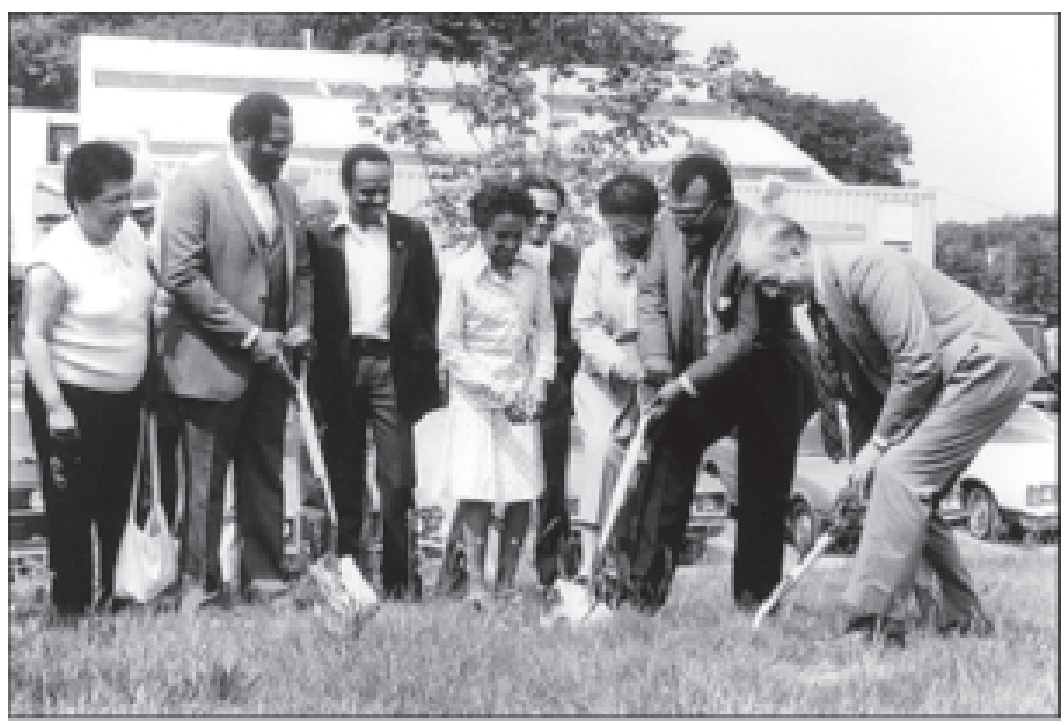

vive, to house and clothe and educate their families. So we must begin with where the people are in the circumstances in which we find them. The urban industrial centers have their own history. In Anacostia it is one of crime, drugs, unemployment, inadequate housing sanitation, rats, to mention but a few of its problems. (Kinard 1972b)

Anacostia Neighborhood Museum åpnet høsten 1967, i lokalene til en nedlagt kino som hadde blitt ombygd og innredet ved dugnad av frivillige tenåringer. Museet ble raskt kjent, også internasjonalt, for sine banebrytende aktiviteter som satte fokus på Anacostias svarte befolknings historie og aktuelle situasjon.

I løpet av 80-årene gjennomgikk museet en forvandling og begynte å henvende seg til et større og mer najonalt publikum. Nærmiljøperspektivet ble mer og mer nedtonet, til fordel for aktiviteter som la vekt på den afro-amerikanske historie og kultur i USA i bredere fors- tand. Tradisjonelle museumsaktiviter som gjenstandsinnsamling ble opprioritert, og historisk forskning i akademisk betydning fikk større plass enn den tidligere aksjonforskning basert på «oral history».

I 1987 flyttet museet ut fra sitt nærmiljø for å etablere seg i et nytt bygg i Fort Stanton Park, i en roligere og mer velstående del av Washington. Samtidig, som følge av «the museum's increased mandate to examine, preserve, and interpret African American history and culture, not only locally and regionally, but nationally and internationally as well», ble navnet skiftet fra «Anacostia Neighborhood Museum» til «Anacostia Museum».

Mot slutten av 1980-årene begynte The Smithsonian å arbeide med planer om opprettelse av "the African American Museum», dvs. en ny nasjonal institusjon etter samme modell som the National Museum of the American Indian, som skulle plasseres sentralt på The 
Mall. Planene ble nedlagt i midten av 1990 årene; det viste seg vanskelig å få dem finansiert på grunn av Kongressens politiske sammensetning. Samtidig var The Smithsonian preget av et ideologisk skifte; i 1995 ga den nye direktør Michael Heyman offentlig uttrykk for sin skepsis for verdien av å etablere «ethnic-specific museums».

I 1995 ble dette prosjektet om et nasjonalt afro-amerikansk museum slått sammen med Anacostia Museum, og den nye institusjonen ble kalt "Anacostia Museum and Center for African American History and Culture». Museets anlegg i Fort Stanton Park har nylig gjennomgått en omfattende ombygging og utvidelse, for blant annet å gi bedre mulighet til å arbeide med den afro-amerikanske materielle kultur, noe som er definert som museets hovedsatsingsområde.

As the Smithsonian Institution's museum of African American history and culture, the Museum explores American history, society, and creative expression from an African American perspective. The museum encourages the collection, protection, and preservation of materials that reflect the history and traditions of families, organizations, individuals, and communities. (<http://anacostia.si.edu/>)

Etablering av den nye institusjonen Anacostia Museum and Center for African American History and Culture kan sees som en realistisk løsning i en ugunstig politisk situasjon, som umuliggjorde opprettelsen av et eget nasjonalt afro-amerikansk museum. Men kritiske røster hevder at saken er betegnende for afro-amerikanernes stilling i USA. Deres kultur har enda ikke fătt det nasjonale monumentet den fortjener, sammen med blant annet the National Museum of the American Indian og det nyere Holocaust Museum, sentralt plassert på The Mall, USAs symbolske senter.

\section{LitTERATUR}

American Association of Museums. 1972. Museums: their New Audience. A report to the Department of Housing and Urban Development by a Special Committee of the American Association of Museums. Washington D.C.

Dennis, Emily. 1970. Seminar on Neighborhood Museums. Museum News (january):13-19

Dennis Harvey, Emily \& Friedberg, Bernard (ed.). 1971. A museum for the people - a report of proceedings at the Seminar on Neighborhood Museums. held nov. 1969 at MUSE in Brooklyn. New York Gjestrum, John Aage, 1996 En bibliografi om økomuseer, Nordisk Museologi 1996/2:57-70

Gjestrum, John Aage \& Maure, Marc (ed.),1988. Økomuseumsboka - identitet, økologi, deltakelse. Tromsø

Hudson, Kenneth 1987. Museums of Influence. Cambridge

Kinard, John \& Nighbert, Esther. 1968. The Smithsonian's Anacostia Neighborhood Museum. Curator 11:190-205

Kinard, John. 1972a. To meet the Needs of Today's Audience. Museum News (may): 15-16

Kinard, John. 1972b. Intermediaries Between the Museum and the Community. in Proceedings of ICOM's 9th General Conferance in Grenoble 1971. Paris

Kinard, John \& Nighbert, Esther. 1972c. The Anacostia Neighborhood Museum, Smithsonian Institution, Washington D.C.. Museum (24), 103-109

Kinard, John. 1985. The neighbourhood museum as a catalyst for social change. Museum (4) vol. 37: 217-222

Marsh, Caryl. 1968. A Neighborhood Museum that works. Museum News (47/2): 11-16

Newson, Barbara \& Siver, Adele (ed.). 1978. Anacostia Neighborhood Museum: a model of community control. In The Art Museum as Educatora Collection of Studies. Berkeley 